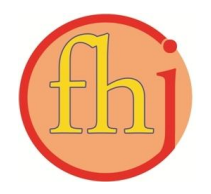

Faletehan Health Journal, 7 (1) (2020) 52-61

www. journal.Ippm-stikesfa.ac.id/ojs/index.php/FHJ

ISSN 2088-673X | e-ISSN 2597-8667

\title{
Literature Review: Pengalaman Perawat Terkait Pelaksanaan Cultural Competence Di Ruang Intensive Care Unit
}

\author{
Yeni Binteriawati ${ }^{1 *}$, Tuti Pahriah ${ }^{2}$, Aan Nuraeni ${ }^{2}$ \\ ${ }^{1}$ Rumah Sakit dr Dradjat Prawiranegara, Kabupaten Serang, Banten \\ 2 Program Paskasarjana, Fakultas IImu Keperawatan, Universitas Padjadjaran, Bandung \\ *Corresponding Author: binter_yeni@yahoo.com
}

\begin{abstract}
Abstrak
Intensive Care Unit (ICU) merupakan area kegiatan asuhan yang dikondisikan dan dirancang dengan baik untuk mengobati kondisi kritis, perawat harus memikili kopetensi budaya yang baik. Budaya memainkan peran besar dalam nilai - nilai, keyakinan, prilaku dan penilaian situasional terkait dengan kesehatan. Bila tidak ditangani akan mengakibatkan konsekuensi sosial dan klinis yang negatif, lingkungan yang tidak jelas, kebingungan, pesan tidak tersampaikan, ketidaktahuan pasien, keterlambatan informed consent dan kualitas perawatan yang rendah. Tujuan penelitian ini untuk menggambarkan pengalaman perawat terkait pelaksanaan Cultural Competence di ICU dari penelitian - penelitian yang sudah dilakuan. Metode yang digunakan dengan pencarian eletronik artikel terdiri dari studi kualitatif yang dikumpulkan dari basis data elektronik seperti Medline, Google Scholar, Science Direct, PubM ed dan Proquest dengan menggunakan kata kunci MeSH yang relevan yaitu : Cultural Competence, Intensive Care Unit, dan Nursing. Artikel yang dipilih sesuai dengan kriteria SPIDER, diterbitkan tahun 2012-2018, ditulis dalam bahasa Inggris. Evaluasi artikel menggunakan penilaian kritis dan pedoman PRISMA. Dari hasil penelurusan literatur yang dilakukan, ditemukan sebanyak 7 (tujuh) artikel terkait dan memenuhi kriteria. Hasil tema - tema yang muncul terkait pelaksanaan cultural competence diantaranya keterlibatan (partisipasi) keluarga dalam proses perawatan, mengunakan penerjemah, mempertahankan tim yang multikultural, komunikasi prosedur dan diagnosa yang jelas dan mengakui keanekaragaman budaya.
\end{abstract}

Kata Kunci: Cultural Competence, Intensive Care Unit, Perawat

\section{Literature Review: Experience of Nurses Related to the Implementation of Cultural Competence in Intensive Care Unit}

\begin{abstract}
Intensive Care Unit (ICU) is an area of care activity and well designed to treat critical conditions, nurses must have cultural competence. Culture participates in health values, beliefs, behavior and situational judgments. If left untreated will result in negative social and clinical consequences, unclear environment, confusion, messages not delivered, patient ignorance, delay in informed consent and low quality of care. The purpose of this study is to describe the experience of nurses related to the implementation of Cultural Competence in the ICU from research that has been done. The method used by searching electronic articles consists of qualitative studies collected from electronic databases such as Medline, Google Scholar, Science Direct, PubM ed and Proquest using relevant MeSH keywords: Cultural Competence, Intensive Care Unit, and Nursing. Articles selected according to the SPIDER criteria, published in 2012-2018. Evaluation of articles uses critical appraisal and PRISMA guidelines. From the results of the literature search conducted, as many as 7 (seven) related articles were found and met the criteria. The results of the themes that emerged related to the implementation of cultural competence include the involvement of the family in the care process, using translators, maintaining a multicultural team, communication procedures, and clear diagnosis and recognizing cultural diversity.

Keywords: Cultural Competence, Intensive Care Unit, Nursing
\end{abstract}


Faletehan Health Journal, 7 (1) (2020) 52-61

www. journal.Ippm-stikesfa.ac.id/ojs/index.php/FHJ

ISSN 2088-673X | 2597-8667

\section{Pendahuluan}

Intensive Care Unit (ICU) merupakan area kegiatan medis yang dikondisikan dengan baik dan disesuaikan untuk mengobati kondisi yang mengancam jiwa dan kritis. Menurut Keputusan Kementrian Kesehatan NO 1778 (2010) disebutkan bahwa ruang ICU adalah suatu bagian dari rumah sakit yang mandiri dengan staf dan perlengkapan yang khusus. Ruang ICU ditujukan untuk observasi dan terapi pasien yang menderita penyakit mengancam nyawa, sehingga dibutuhkan perawatan yang cepat tepat cermat dan aman secara holistic baik pada bio, psiko, sosial spiritual budaya dan politik, hal yang penting untuk memenuhi kebutuhan dasar manusia (Leininger dan McFarland, 2002).

Perawat dan lingkungan ICU merupakan hal asing / baru bagi pasien, kedaan pasien yang kritis mengakibatkan semua pemenuhan kebutuhan diambil alih perawat. Perubahan yang mendadak dan kondisi pasien yang kritis akan mengakibatkan stres pada klien sampai menimbulkan konflik. Menurut penelitian Benbenishty dan Biswas (2015) konflik di ICU berkaitan dengan stres pasien dan keluarga yang bersumber dari kondisi pasien yang berat, prosedur mendesak serta persetujuan untuk membuat keputusan yang cepat.

Menurut Høye dan Severinsson (2010) budaya yang beragam membawa keyakinan dan pemahaman yang berbeda terhadap situasi perawatan yang dapat berdampak pada proses perawatan. Klien cenderung mempertahankan tradisi dan perawat harus melaksanakan asuhan keperawatan sesuai keilmuannya, sebagai contoh dalam pengambilan keputusan klien harus melibatkan keluarga sehingga memperlambat pembuatan keputusan sedangkan perawat harus membuat keputusan yang cepat dan tepat terkait kondisi pasien yang dalam kedaan kritis. Dampak dari perbedaan budaya juga di sampaikan dalam penelitian Hendson, Reis, Nicholas dan Hendson (2015) yang menyatakan bahwa perbedaan budaya dapat menyebabkan konflik yang berkaitan dengan hambatan budaya terutama bahasa pada saat pasien di rawat di ICU.

Dampak dari pelaksanaan asuhan yang tidak memperhatikan budaya pasien adalah kegagalan interaksi yang menghambat komunikasi, pada pasien kritis hambatan komunikasi ini akan mengganggu proses pengambilan keputusan yang cepat dan tepat selain itu perbedaan norma, keyakinan, dan bahasa dapat juga menimbulkan konflik, dan konflik terjadi terjadi ketika perilaku budaya dominan dan non dominan bertemu (Høye \& Severinsson, 2010). Konflik lain yang dapat timbul adalah hambatan komunikasi efektif dan interaksi perawat dengan klien yang berdampak stress pada perawat hal ini seperti pada penelitian Hendson et. al, (2015 yang menyatakan bahwa perawat yang tidak memiliki cultural competence mengakibatkan perasaan menyalahkan diri sendiri dan menyalahkan orang lain. Hal ini dapat disebabkan oleh stereotip yang melekat pada perawat, waktu yang terbatas perawat dalam berinteraksi antara perawat dan pasien sehingga kurang terbangun kepercayaan dan menurunnya intuisi perawat terhadap kebutuhan pasien terutama pada pasien baru.

Pasien memiliki budaya sendiri yang dipegang erat begitu juga perawat memiliki budaya pribadi yang dipercaya dan budaya profesional sebagai perawat. Hal ini ketika tidak disertai dengan toleransi dan adaptasi dari kedua belah pihak akan menimbulkan konflik yang dapat menggangu perawatan pasien sehingga menyebabkan timbulnya kesalahpahaman yang mengarah pada kepuasan pasien yang rendah dan bahkan kesalahan dalam prosedur medis dan keperawatan (Ozga et al., 2018). Bahkan menurut penelitian Curwick et. al, (2015) menyatakan bahwa $80 \%$ perawat harus memiliki cultural competence di ICU.

Cultural Competence yang dimiliki perawat menunjukkan pengetahuan dan pemahaman tentang budaya pasien, menerima dan menghormati perbedaan budaya dan menyesuaikan perawatan agar selaras dengan budaya pasien (Campinha-Bacote, 2002 dalam Schime et. al, 2007). Masih menurut (CampinhaBacote, 2002 dalam Schime et. al, 2007), ada lima faktor yang harus dimiliki perawat yang merupakan faktor utama dari cultural competence di tingkat penyedia layanan kesehatan yaitu kesadaran budaya (cultural awareness), pengetahuan budaya (cultural knowledge), keterampilan budaya (cultural skill), pertemuan budaya (cultural encounters), keinginan budaya (cultural desire). Perawat yang memiliki cultural competence akan selaras secara budaya dan akan bertindak atau membuat keputusan dengan mempertimbangkan aspek kognitif, suportif, 
fasilitatif atau dukungan yang disesuaikan dengan nilai-nilai budaya, kepercayaan, dan budaya individu, kelompok atau institusional untuk memberikan atau mendukung layanan kesehatan atau layanan kesejahteraan yang bermakna, bermanfaat dan memuaskan (Leininger 1991, dalam Hart dan Mareno, 2017). Perawat harus memiliki cultural competence yang baik, agar dapat mengefektifkan komunikasi pada proses pemberian asuhan sehingga meningkatkan kenyamanan klien. Penelitian yang dikemukakan oleh Ardal, Sulman dan Fuller (2011) menyebutkan bahwa manusia cenderung mencari orang yang memiliki budaya yang sama atau memahami budaya yang dianutnya dalam memberikan kepercayaan dan menimbulkan rasa aman.

Menurut penelitian Schim et al, (2007) perawat belum memahami tentang cultural competence yang baik. Sedangkan mengenai budaya yang dianut pasien, perawat mengatakan kadang terganggu dengan budaya tersebut dan keluarga sangat tidak memahami kedaan yang berkaitan dengan prinsip yang bertolak belakang antarabudaya dengan aturan rumah sakit, hal ini sesuai dengan hasil penelitian yang menyatakan bahwa "keluarga pasien akan berusaha mempertahankan tradisi, disisi lain perawat tidak cukup sadar budaya" (Høye \& Severinsson, 2010). Pelaksanaan budaya pasien terakit kesehatan terkadang bertolak belakang dengan asuhan keperawatan yang dilakukan pada pasien seperti pengunaan obat - obat alternatif yang dipercaya membantu penyembuhan, penanganan pasien menjelang kematian juga biasanya memiliki perbedaan antara perawat dank kien, hal ini dapat menimbulkan permasalahan yang akan menanggu asuhan keperawatan yang baik (Schim et al, 2007).

Penelitian-penelitian terkait cultural competence banyak dilakukan di negara maju yang memiliki banyak budaya yang berbeda akibat banyaknya imigran yang masuk, ditambah kesadaran yang baik dari para pekerja kesehatan yang melaksanakan asuhan yang ramah budaya sehingga penelitian terkait cultural competence banyak di negara tersebut (Wiebe dan Young, 2011). Beberapa penelitian yang sudah dilakukan di area kritis tentang cultural competence banyak membahas tentang pentingnya hal tersebut dimiliki oleh perawat, akan tetapi penelitian tersebut hanya membahas terkait konsep dan model - model keperawatan yang berdasarkan budaya seperti penelitian Almutuari (2015) terkait model critical cultural competence, penelitian tersebut serupa dengan penelitian Unger \& Schwartz, (2012) tentang model konsep akulturasi, penelitian Ozga, Dobrowolska, Gutysz-wojnicka, \& Zdun, (2018) tentang model multicultural care in European Intensive Care Units (MICE-ICU). Ada pun beberapa penelitian terkait pelaksanaan cultural competence di area kitis seperti penelitian Hendson, Reis dan Nicholas, (2015) yang meneliti pelaksanaan cultural competence di NICU dan penelitian Hoye dan Severinsson, (2010) terkait budaya dan profesioanalisme perawat di ICU.

Pelaksanaan cultural competence harus dilakukan dengan baik dan ditingkatkan agar menjamin keselamatan pasien dan peningkatan kualitas pelayanan asuhan keperawatan. Hal ini harus didukung dengan penelitian - penelitian untuk meningkatkan kompetensi perawat terutama dalam bidang budaya. Pada perkembangan perawat di Indonesia penelitian cultural competence berbanding terbalik dengan perkembangan penelitian cultural competence di negara non Asia. Penelitian terkait cultural competence masih belum banyak dilakukan di Asia, bahkan di negara Korea hanya ada dua penelitan terkait pelaksanaan cultural competence (Chae \& Park, 2018). Hal ini disebabkan salah satunya karena cultural competence masih diangap sebagai hal yang kurang penting dibanding dengan faktor - faktor lain dalam perawatan pasien apalagi pasien dengan kondisi kritis. Indonesia sebagai Negara yang multietnis dengan keanekaragaman budaya dimana konflik terkait perbedaan sangat mungkin akan timbul, bahkan sudah terjadi dan dapat kita lihat di berbagai daerah termasuk di area rumah sakit. Sehingga sangat penting untuk dilkaukanya penelitian terkait pelaksanaan cultural competence yang sudah dilakukan dalam penelitian sebelumnya untuk menjadi acuan dalam penelitian yang akan dilakukan dan peningkatan pengetahuan terkait pengalaman perawat dalam pelaksanaaan cultural competence.

\section{Metode Penelitian}

Metode yang digunakan adalah dengan pencarian eletronik artikel terdiri dari studi kualitatif yang dikumpulkan dari basis data elektronik seperti Medline, Google Scholar, 
Faletehan Health Journal, 7 (1) (2020) 52-61

www. journal.Ippm-stikesfa.ac.id/ojs/index.php/FHJ

ISSN 2088-673X | 2597-8667

Science Direct, PubMed dan Proquest dengan menggunakan kata kunci MeSH yang relevan yaitu : Cultural Competence, Intensive Care Unit, dan Nursing. Artikel yang dipilih yaitu sesuai dengan kriteria SPIDER, diterbitkan tahun 20122018, ditulis dalam bahasa Inggris, evaluasi artikel menggunakan penilaian kritis dan pedoman PRISMA (preferred reporting items for systematic reviews and metaanalyses)

\section{Hasil dan Pembahasan}

Cultural competence merupakan pengembangkan kesadaran akan eksistensi, sensasi, pikiran, dan lingkungan diri seseorang tanpa terpengaruh oleh hal - hal yang tidak semestinya pada seseorang dari latar belakang yang berbeda. Cultural Competence perawat menunjukkan pengetahuan dan pemahaman tentang budaya pasien; menerima dan menghormati perbedaan budaya; menyesuaikan perawatan agar selaras dengan budaya pasien (Flower, 2017). Giger dan Davidhizar dalam Karabudak, Aslan \& Basbakkal, (2013) mengungkapkan bahwa cultural competence perawat merupakan perawat yang memiliki pengetahuan, pemahaman, dan keterampilan tentang kelompok budaya yang beragam yang memungkinkan penyedia layanan kesehatan memberikan perawatan budaya yang dapat diterima. Cultural competence adalah proses yang berkelanjutan yang melibatkan tidak hanya perawat yang memperoleh pengetahuan dan keterampilan untuk bekerja dengan pasien dan keluarga yang beragam secara budaya, tetapi kemampuan untuk memberikan perawatan dalam konteks budaya pasien dan keluarga (CampinhaBacote 2007).

Cultural competence memiliki sejarah panjang dalam keperawatan. Leininger sebagai seorang pelopor keperawatan di bidang keperawatan transkultural, mendefinisikan perawatan yang kongruen secara budaya adalah tindakan atau keputusan yang berdasarkan kognitif, suportif, fasilitatif atau dukung yang disesuaikan dengan nilai-nilai budaya, kepercayaan, dan budaya individu, kelompok atau institusional untuk memberikan atau mendukung layanan kesehatan atau layanan kesejahteraan yang bermakna, bermanfaat dan memuaskan (Leininger 1991, dalam Hart \& Mareno, 2017).

Cultural competence merupakan aplikasi dari trankultural nursing yang dikemukakan oleh
Leininger tahun 1950. Transkultural keperawatan sekarang dianggap sebagai area keperawatan yang penting baik untuk penelitian dan praktik. Teori ini terpengaruh dari ilmu antropologi dan psikologi kemudian para ahli teori ini mulai menentukan dasar teoritis keperawatan transkultural untuk mendefinisikan budaya pada asuhan keperawatan, lingkungan keperawatan, intervensi keperawatan, dan peran perawat (Im \& Lee, 2018). Menurut Schime at. al, (2007) ada Empat konstruksi dasar yang merupakan bagian utama dari Cultural competence di tingkat penyedia layanan kesehatan: keragaman budaya, kesadaran budaya, kepekaan budaya, dan kompetensi budaya.

Kesadaran budaya merupakan komponen kopetensi budaya dimana melibatkan pemeriksaan diri dan eksplorasi mendalam tentang latar belakang budaya dan profesional seseorang. kesadaran budaya harus dimulai dengan wawasan tentang keyakinan dan nilai kesehatan budaya seseorang. Catalano (2003) dalam Flower (2018) menyatakan bahwa "hanya belajar tentang budaya orang lain tidak menjamin perawat akan memiliki kesadaran budaya, perawat pertama-tama harus memahami latar belakang budaya mereka sendiri dan mengeksplorasi asal usul prasangka mereka sendiri dan pandangan bias orang lain".

Pengetahuan budaya, melibatkan proses pencarian dan memperoleh basis informasi pada kelompok budaya dan etnis yang berbeda. Perawat dapat mengembangkan dan memperluas basis pengetahuan budaya mereka dengan mengakses informasi yang ditawarkan melalui berbagai sumber, termasuk artikel jurnal, buku teks, seminar, presentasi lokakarya, sumber daya Internet, dan program universitas. Sedangkan keterampilan budaya, melibatkan kemampuan perawat untuk mengumpulkan data budaya yang relevan terkait dengan masalah yang ada pada pasien secara akurat dan melakukan pengkajian fisik yang spesifik secara budaya.

Pertemuan budaya merupakan proses yang mendorong perawat untuk secara langsung terlibat dalam interaksi lintas budaya dengan pasien dari latar belakang budaya yang beragam. Langsung berinteraksi dengan pasien dari latar belakang budaya yang berbeda membantu perawat meningkatkan cultural competence mereka. Pengembangan cultural competence adalah proses berkelanjutan yang terus menerus sepanjang 
karier perawat dan terus berkembang tanpa ada batas akhir.

Keinginan budaya merupakan komponen yang mengacu pada motivasi untuk menjadi sadar budaya dan untuk mencari pertemuan budaya. Kemelekatan dalam keinginan budaya adalah kesediaan untuk bersikap terbuka kepada orang lain, menerima dan menghormati perbedaan budaya, dan mau belajar dari orang lain. Kesalahan umum yang harus dihindari agar perawat memiliki cultural competence adalah dengan tidak sengaja membuat stereotip pada pasien dengan budaya tertentu atau kelompok etnis berdasarkan karakteristik seperti penampilan luar, ras, negara asal, atau preferensi keagamaan yang dinanut pasien. Stereotip didefinisikan sebagai konsepsi, opini, atau keyakinan yang terlalu disederhanakan tentang beberapa aspek individu atau sekelompok orang.

Menurut Purnell (2002) dalam Schime at. al, (2007) mendeskripsikan 12 domain budaya yang mempengaruhi keperawatan diantaranya adalah : warisan, komunikasi, peran dan organisasi keluarga, masalah tenaga kerja, ekologi biokultural, perilaku berisiko tinggi, nutrisi, kehamilan dan praktik melahirka, ritual kematian, spiritualitas, praktik perawatan kesehatan, dan peran praktisi kesehatan. Domain tersebut terbangun diantara paradigma masyarakat global, komunitas, keluarga dan personal, yang memiliki budaya yeng berbeda, akan tetapi budaya harus dipandang sama karena tidak ada budaya yang lebih baik dari budaya yang lain. Perawat berhak mendapat informasi yang sama terkait keragaman budaya agar dapat meningkatkan cultural competence.

Model lain dari cultural competence menurut Giger dan Davidhizar dalam Karabudak, Aslan \& Basbakkal, (2013) adalah mode yang memberikan metode sistematis untuk menilai orang yang beragam secara budaya dan etnis. Unsur-unsur model ini adalah komunikasi, ruang, organisasi sosial, waktu, kontrol lingkungan, dan variasi biologis. Model ini dapat digunakan dalam melakukan asuhan keperawatan peka budaya, dimana model ini disederhanakan dari modelmodel asuhan peka budaya sebelumnya. Perawat penting memiliki pemahaman budaya, sikap dan prilaku yang beragam baik dari klien atau petugas kesehatan lainnya untuk meningkatkan pelaksanaan cultural competence (Karabudak, Aslan \& Basbakkal, 2013)
Perawat kritis harus mengembangkan cultural competence agar efektif untuk menjaga kestabilan hubungan perawat kritis dengan pasien, dan dapat menilai, mengembangkan, dan menerapkan intervensi keperawatan yang dirancang untuk memenuhi kebutuhan pasien, selain itu perawat perawatan kritis harus dapat mensiasati keputusan yang dibuat oleh pasien atau keluarga pasien yang mungkin mencerminkan perspektif budaya yang bertentangan dengan praktik kesehatan (Flower, 2004). Pada perkembangan masyarakat saat ini, perawatan kritis harus kompeten secara budaya, dapat memahamani tentang latar belakang budaya yang beragam, mengembangkan kompetensi budaya, menyajikan model untuk pengembangan kompetensi budaya, dan menggambarkan atau menampilkan perawat yang terampil dalam cultural competence.

Setiap perawat kritis harus berperan aktif dalam memperoleh basis informasi untuk mengembangkan cultural competence. Kemampuan untuk memberikan asuhan keperawatan yang efektif dalam interaksi dan pengembangan keputusan yang tepat untuk pasien - pasien dari beragam budaya, ras, dan latar belakang etnis (Flower, 2004). Lima rekomendasi utama untuk meningkatkan cultural competence perawat kritis yakni melibatkan keluarga selama proses perawatan, menggunakan juru bahasa untuk interpretasi yang akurat penyakit dan rasa sakit, mempertahankan tim yang beragam secara budaya sehingga mampu menjelaskan prosedur dan diagnosis pada pasien dan rekomendasi kelima adalah mengakui keragaman budaya.

Adapun pelaksanaan cultural competence di ICU meliputi penyesuaian lingkungan perawatan yang sesuai dengan budaya pasien pasien dan keluarga, perawat harus memahami budayanya sendiri untuk melihat kelebihan dan kekurangan budaya yang dimiliki, mempertahamkan kondisi multicultural, memahami bahasa pasien atau mengunakan penerjemah dan /atau melibatkan keluarga, pemahaman non verbal terkait budaya pasien, agama yang dianut, adaptasi budaya, consent, perawatan end of life dan komunikasi religius dan firasat (Benbenishty \& Biswas, 2015).

Komunikasi efektif merupakan indikator krusial dari kualitas pelayanan kesehatan dan patient safety, hambatan dalam komunikasi yang terjadi di area kritis lebih dititik beratkan pada 
Faletehan Health Journal, 7 (1) (2020) 52-61

www. journal.Ippm-stikesfa.ac.id/ojs/index.php/FHJ ISSN 2088-673X | 2597-8667

masalah budaya dan pemahaman akan budaya pasien oleh perawat, cultural competence di area kritis, hambatan komunikasi dapat diakibatkan oleh perbedaan budaya pasien dan perawat (Almutuari, 2012). Davis dan Smith (2013) mengidentifikasi tiga tantangan utama dalam penyediaan perawatan yang kompeten secara budaya: hambatan bahasa, perbedaan generasi antara perawat dan pasien/keluarga, dan sikap berbasis budaya kuno atau leluhur.

Hambatan yang terjadi pada perbedaan budaya diakibatkan oleh kerapuhan dalam hubungan komunikasi perawat dan klien dan hal hal yang menghambat interaksi dan komunikasi antar budaya di area kritis adalah adalah : Stereotip dimana hambatan yang berkaitan dengan stereotip ketika masyarakat melihat perawat dari sudut pandang yang terbangun selama ini berkaitan dengan prilaku perawat, hal ini dapat menjadi hambatan (Ardal, Sulman \& Fuller, 2011). Hambatan lain yakni rasialisme yang terkait rasa yang besar terhadap ras yang dimiliki seseorang akan mempengaruhi padangan terhadap ras lain terutama ras-ras yang dominan yang akan melihat ras-ras lain berbeda dan bukan tempat yang baik dalam memberikan kepercayaan (Ozga et. al, 2018).

Sikap merupakan hambatan komunikasi yang terkait perbedaan budaya dimana sikap berhubungan dengan waktu terbatas untuk melakukan kegiatan dalam memahami anatara pasien dan perawat. Tuntutan tugas yang berorientasi pada tindakan dan waktu tambahan yang diperlukan untuk membangun hubungan dengan keluarga dan pasien sebagai memaksakan peningkatan beban kerja dan tekanan emosional pada penyedia layanan kesehatan, terutama perawat, namun merupakan aspek penting untuk memberikan perawatan yang tepat dan memuaskan klien (Benbenishty et. al, 2017).

Persepsi intuitif tentang kebutuhan keluarga. Kemampuan perseptif terhadap norma-norma budaya yang beragam seperti kesopanan, privasi, kontak mata, dan sentuhan digambarkan memiliki pengaruh signifikan pada kemampuan penyedia layanan kesehatan untuk menyampaikan penghormatan terhadap budaya klien (Ozga et. al, 2018). Persepsi intuitif ini salah satu hambatan dalam berkomunikasi dan membutuhkan kompetensi budaya dari perawat dalam menangani hal ini, ketika pelaksanaan cultural competence baik maka persepsi intuitif menjadi hal yng baik karena perawat dapat memahamni budaya yang dianut klien dengan benar.

Hambatan dalam komunikasi dan merupakan berasal dari budaya klien adalah bahasa. Bahasa yang dimiliki di suatu wilayah bisa sangat berbeda satu dengan yang lain selain dari pemahaman yang sulit dalam penerjemahan, bahasa yang sama dengan berbeda makna akan menimbulkan salah faham, pada penelitian di Amerika, rumah sakit yang menerima pasien imigran dari Meksiko dengan perbedaan bahasa banyak menimbulkan konflik terutama para imigran yang tidak dapat mengikuti aturan rumah sakit karena tidak menemukan perawat dengan bahasa yang mereka fahami dan para keluarga yang cemas ketika di rawat oleh perawat yang berbeda bahasa (Hendson et. al, 2015). Perawat mengatakan bahwa kemampuan berbicara bahasa yang sama dengan pasien memungkinkan hubungan yang lebih besar dengan pasien dan keluarga.

Dalam penelitian sebelumnya, perawat telah melaporkan bahwa kemampuan untuk berbicara dalam banyak bahasa meningkatkan perawatan yang kompeten secara budaya (El-Amouri \& O'Neill 2011; Starr \& Wallace 2009). Beberapa perawat dalam penelitian ini berkomentar bahwa kursus bahasa perlu menjadi prioritas yang lebih tinggi dalam program gelar keperawatan. Davis dan Smith (2013) mengemukakan bahwa pengawas individu yang memberikan perawatan langsung kepada pasien dan keluarga dengan beragam budaya mempertimbangkan kursus bahasa yang berfokus pada pembelajaran bahasa profesional dan sehari-hari sebagai prioritas.

Keyakinan dalam organisasi perawatan kesehatan, komunikasi lintas-budaya yang tidak ditangani dengan baik dapat menyebabkan konsekuensi sosial dan klinis yang negatif, lingkungan yang tidak pasti atau kesalahpahaman, kebingungan bagi pasien dan keluarga, adanya asuhan yang tidak efisien, ketidakpatuhan pasien, keterlambatan dalam memperoleh informed consent dan penurunan kualitas perawatan (American College of Physicians, 2004 dalam Unger, 2012). Menurut Schim, et. al (2007) agar budaya dapat kongruen dengan asuhan perawatan maka diperlukan pertama adalah evaluasi hasil asuhan yang berbasis budaya dilakukan dari sudut pandang penerima dan penyedia perawatan, kedua perawat harus memiliki kompetensi spesifik (kognitif, afektif, dan psikomotor) kemudian diaplikasikan, dipelajari, dan diidentifikasi dalam 
praktek asuhan keperawatan, ketiga adalah ruang lingkup cultural competence harus meliputi pemahaman jumlah dan ragam kelompok orang yang ditemui dalam konteks komunitas, sosial dan layanan. Keempat adalah kedalaman kompetensi terkait dengan jumlah keterpaparan dan jenis interaksi dengan kelompok masyarakat yang ditemui dalam konteks komunitas, sosial, dan layanan.

Faktor-faktor diatas yang dapat menghambat komunikasi akibat perbedaan budaya akan mengakibatkan konflik antara perawat dan klien. Hal ini dapat terjadi di semua area rumah sakit, dapaun hambatan komunikasi yang dapat terjadi di ICU yang dialami perawat menurut penelitian Arumsari, Emaliyawati dan Sriati (2016) yaitu konflik peran, faktor demografi keluarga, kesalahpahaman, lingkungan dan situasi di ICU, dan kondisi psikologis keluarga.

Intensive care unit menyediakan kemampuan dan sarana prasarana serta peralatan khusus untuk menunjang fungsi-fungsi vital dengan menggunakan ketrampilan medik, perawat dan staf lain yang berpengalaman dalam pengelolaan keadaan tersebut. Asuhan keperawatan yang bermakna dan sesuai dengan budaya pasien bertujuan untuk membantu dan mengarahkan tindakan dan keputusan keperawatan yang didasari oleh pemeliharaan atau pelestarian perawatan berbasis budaya (Ozga et al., 2018). Adapun hal yang harus dilakukan perawat terkait budaya milik pasien adalah dengan cara akomodasi, negosiasi dan restrukturisasi atau reorganisasi budaya untuk memungkinkan perawat dapat melaksanakan asuhan yang disesuaikan dengan budaya yang dimiliki pasien agar dapat membantu asuhan dan tidak mengganggu asuhan keperawatan pada pasien.

Pada penelitian Ardal, Sulman dan Fuller, (2011) didapat tema bahwa perawat merasa hubungan interaksi dengan pasien yang memiliki budaya yang berbeda memiliki sifat yang rapuh atau tidak terbentuknya kepercayaan yang baik, masa krisis juga pasien dan steriotip yang tumbuh dimasyarakat tentang pelayanan perawat pada klien dengan berbeda budaya, hal lain yang didapat bahwa perawat menyatakan "keluarga lebih memilih perawat dengan pemahaman budaya yang baik atau memiliki budaya yang sama dalam menyerahkan kepercayaan terhadap perawatan pasien".

Rekomendasi Deklarasi Brisbane yang ditulis pada tahun 2016 tentang pedoman (guideline) untuk perawat ICU mengenai pasien dengan latar belakang budaya yang berbeda yaitu : Melibatkan (partisipasi) keluarga dalam proses perawatan, Mengunakan penerjemah untuk terjemahan yang tepat dari catatan kasus penyakit dan rasa sakit, Mempertahankan multikultural tim penyedia layanan, Komunikasi prosedur dan diagnosa yang jelas, dan mengakui keanekaragaman budaya.

Pada penelitian terkait pengalaman perawat dalam pelaksanaan cultural competence di ICU ditemukan tema utama yaitu 'konflik antara praktik keperawatan profesional dan tradisi budaya keluarga' yang didasari dari tiga tema yang muncul diantaranya kebutuhan berbasis budaya untuk berpartisipasi aktif dalam persepsi profesional perawat dengan perawat tentang diri mereka sebagai penyedia layanan total, kewajiban profesional perawat untuk memberikan informasi yang dapat dipahami dengan kesulitan komunikasi berbasis budaya dan respons terhadap penyakit dan kebutuhan keluarga untuk norma budaya dan penentuan nasib sendiri dengan tanggung jawab profesional perawat untuk lingkungan klinis (Høye dan Severinsson, 2009).

Pengalaman penerapan cultural competence di ICU di paparkan juga oleh penelitian dari Benbenishty \& Biswas, (2015) yang mengatakan bahwa cultural competence di area kritis adalah area yang penuh tantangan baik secara fisik maupun mental, sehingga semua pekerjaan yang berkaitan dengan pasien dan rekan kerja dibutuhuhkan kopetensi budaya perawat dan perawat harus memandang semua budaya setara dan harus dihormati, terutama saat melakukan tindakan seting cairan intravena, perpindahan pasien dan perawatan luka. Dan pada tindakan krusial lainnya yang membutuhkan kerjasama antar perawat, maka perawat juga harus memiliki perlakuan yang sama terhadap teman sejawat terkait penghormatan terhadap budaya yang dianut rekan kerjanya.

Hasil lain pada penelitian terkait pelaksanaan cultural competence di ICU mengungkapkan bahwa perawat harus memiliki keterampilan eksplorasi arti penyakit untuk pasien, penentuan konteks sosial di mana pasien tinggal, keterlibatan dalam negosiasi dengan pasien untuk mendorong komunikasi yang efektif dan kepatuhan terhadap pengobatan, dan eksplorasi persepsi pasien tentang perlakuan yang mereka terima (Benbenishty et al., 2018). 
Faletehan Health Journal, 7 (1) (2020) 52-61

www. journal.Ippm-stikesfa.ac.id/ojs/index.php/FHJ

ISSN 2088-673X | 2597-8667

Tabel 1. Hasil Penelusuran Artikel

\begin{tabular}{|c|c|c|c|}
\hline No & Judul & Peneliti & Hasil \\
\hline 1 & $\begin{array}{l}\text { Multicultural Care in } \\
\text { European } \\
\text { Care Untensive } \\
\text { ICU) - international } \\
\text { project for ICU nurses }\end{array}$ & $\begin{array}{l}\text { Ozga, } \\
\text { Dobrowolska, B., } \\
\text { Gutysz-wojnicka, } \\
\begin{array}{ll}\text { A., \& Zdun, A. } \\
(2018) .\end{array}\end{array}$ & $\begin{array}{l}\text { 1. keterlibatan (partisipasi) keluarga dalam proses } \\
\text { perawatan, } \\
\text { 2. mengunakan penerjemah untuk terjemahan yang tepat } \\
\text { dari catatan kasus penyakit dan rasa sakit, } \\
\text { 3. mempertahankan multikultural tim penyedia layanan, } \\
\text { 4. komunikasi prosedur dan diagnosa yang jelas, dan } \\
\text { 5. mengakui keanekaragaman budaya. }\end{array}$ \\
\hline 2 & $\begin{array}{l}\text { The migrant crisis and } \\
\text { the importance of } \\
\text { developing cultural } \\
\text { competence in the } \\
\text { intensive care unit. }\end{array}$ & $\begin{array}{l}\text { Benbenishty, J., } \\
\text { Harth, I., Barkestad, } \\
\text { E., Satosek, D., } \\
\text { Jacobsson, K., \& } \\
\text { Blackwood, } \\
\begin{array}{l}(2017) \\
\text { B. }\end{array}\end{array}$ & $\begin{array}{l}\text { Perawatan setiap pasien menggunakan keterampilan } \\
\text { berikut: eksplorasi arti penyakit kepada pasien; penentuan } \\
\text { konteks sosial di mana pasien tinggal; keterlibatan dalam } \\
\text { negosiasi dengan pasien untuk mendorong komunikasi yang } \\
\text { efektif dan kepatuhan terhadap pengobatan; dan eksplorasi } \\
\text { persepsi mereka tentang perlakuan yang mereka terima. }\end{array}$ \\
\hline
\end{tabular}

3 Health Care Providers' Hendson, Reis and Penyedia layanan kesehatan mengidentifikasi konstruksi Perspectives of Nicholas, 2014 bernuansa interaksi rapuh yang tertanam dalam perawatan Providing Culturally keluarga imigran baru di NICU. Selama krisis, pengambilan Competent Care in the keputusan, perbedaan norma dan keyakinan, dan bahasa NICU dan komunikasi adalah hambatan yang mempengaruhi sifat interaksi yang rapuh. Selama masa transisi, interaksi yang rapuh dipengaruhi oleh stereotip yang tidak disengaja, waktu yang terbatas untuk kegiatan tidak berwujud (kegiatan yang bersifat interaksi dengan keluarga), dan kurangnya persepsi intuitif perawat akan kebutuhan keluarga imigran baru. Petugas kesehatan menggunakan strategi peduli budaya dan kompeten budaya untuk mengatasi sifat interaksi yang rapuh

4 Cultural Competence in Benbenishty Critical Care: Case Biswas, 2015

\& Area kritis adalah area yang penuh tantangan baik secara fisik maupun mental,

Studies in the ICU

Perawat harus memandang semua budaya setara dan harus di hormati.

5 Cultural Competence In Curwick K, Dutt (1) melibatkan keluarga selama proses perawatan; (2) Acute and Critica care T.(2015) menggunakan juru bahasa untuk interpretasi akurat Medicine: Literature Review and Recomendatione. penyakit dan rasa sakit; (3) mempertahankan tim penyedia yang beragam secara budaya; (4) menjadi jelas dalam komunikasi prosedur dan diagnosis; (5) mengakui keragaman budaya.

6 Professional and Høye, S., \& 'konflik antara praktik keperawatan profesional dan tradisi cultural conflicts for Severinsson, E. budaya keluarga', didasarkan pada tiga pasang tema yang intensive care nurses (2010). saling bertentangan: 'kebutuhan berbasis budaya untuk berpartisipasi aktif dalam persepsi profesional perawat vs perawat tentang diri mereka sebagai penyedia layanan total'; 'Kewajiban profesional perawat untuk memberikan informasi yang dapat dipahami vs. kesulitan komunikasi berbasis budaya dan respons terhadap penyakit'; dan kebutuhan 'keluarga' untuk norma budaya dan penentuan nasib sendiri vs. tanggung jawab profesional perawat untuk lingkungan klinis '. Selain itu, setiap pasangan tema berisi beberapa sub-tema.

\begin{tabular}{llll}
\hline 7 & Almutairi's $\quad$ Critical & Almutairi, Dahinten & Model ACCC dapat mempromosikan atau mengganggu \\
Cultural Competence & dan Rodney, 2017 & $\begin{array}{l}\text { proses memperoleh kompetensi budaya, yang pada } \\
\text { akhirnya mempengaruhi kualitas hasil perawatan kesehatan }\end{array}$ \\
& model for a & & $\begin{array}{l}\text { akn kesehatan. } \\
\text { multicultural healthcare }\end{array}$
\end{tabular}


Hasil yang didapatkan dari penelitian tersebut, didapatkan area kritis adalah area yang penuh tantangan baik secara fisik maupun mental, sehingga semua pekerjaan yang berkaitan dengan pasien dan rekan kerja dibutuhuhkan kepetensi budaya perawat dan perawat harus memandang semua budaya setara dan harus di hormati.Sebagian besar artikel yang ditinjau (80\%) menekankan peran perawat dalam perawatan yang kompeten secara budaya. Lima rekomendasi utama untuk meningkatkan kompetensi budaya ditekankan dalam mayoritas artikel: (1) melibatkan keluarga selama proses perawatan; (2) menggunakan juru bahasa untuk interpretasi akurat penyakit dan rasa sakit; (3) mempertahankan tim penyedia yang beragam secara budaya; (4) menjadi jelas dalam komunikasi prosedur dan diagnosis; (5) mengakui keragaman budaya.

Dalam penelitian ini ditemukan Tema utama, 'konflik antara praktik keperawatan profesional dan tradisi budaya keluarga', didasarkan pada tiga pasang tema yang saling bertentangan: 'kebutuhan berbasis budaya untuk berpartisipasi aktif dalam persepsi profesional perawat vs perawat tentang diri mereka sebagai penyedia layanan total'; 'Kewajiban profesional perawat untuk memberikan informasi yang dapat dipahami vs. kesulitan komunikasi berbasis budaya dan respons terhadap penyakit'; dan kebutuhan 'keluarga' untuk norma budaya dan penentuan nasib sendiri vs tanggung jawab profesional perawat untuk lingkungan klinis. Selain itu, setiap pasangan tema berisi beberapa sub-tema. Hasil yang didapatkan dari penelitian ini didapatkan bahwa konteks dapat mempromosikan atau mengganggu proses memperoleh kompetensi budaya, yang pada akhirnya mempengaruhi kualitas hasil perawatan kesehatan dan kesehatan.

\section{Simpulan}

Hasil penerapan cultural competen di ICU merupakan kesadaran dan peka budaya dalam asuhan keperawatan yang tercermin dalam kemampuan perawat dalam menerima adat budaya klien dan kemampuan perawat mengenali budayanya sendiri serta belajar dalam memahami budaya sekitar baik hubungan perawat dengan perawat, perawat dengan klien dan perawat dengan profesi lain.

\section{Referensi}

Albougami, A. S., Pounds, K. G., \& Alotaibi, J. S. (2016). Nursing and Health Care Comparison of Four Cultural Competence Models in Transcultural Nursing: A Discussion Paper ClinMed, 2(4), 1-5.

Almutairi, A. F. (2012). A case study examination of the influence of cultural diversity in the multicultural nursing workforce on the quality of care and patient safety in a Saudi Arabian hospital, (January).

Almutairi, A. F. Susan, V., \& Rodney, P. (2015). Almutairi' s Critical Cultural Competence model for a multicultural healthcare environment, 22(4), 317-325. https://doi.org/10.1111/nin.12099.

Benbenishty, J., Harth, I., Barkestad, E., Satosek, D., Jacobsson, K., \& Blackwood, B. (2017). The migrant crisis and the importance of developing cultural competence in the intensive care unit, 22(5), 262-263. https://doi.org/10.1111/nicc.12313

Benbenishty, J., Biswas, S. (2015). Cultural Competence in Critical Care: Case Studies in the ICU. Journal of Modern Education Review, 5(7), 723-728. https://doi.org/10.15341/jmer(21557993)/07.05.2015/011

Campinha-bacote, J. (2002). The Process of Cultural Competence in the Delivery of Healthcare Services: A Model of Care, 13(3), 181-184.

Catalano J. (2003). Nursing Now: Today's Issues, Tomorrow's Trends.3rd ed. Philadelphia, Pa: FA Davis;:393-411.

Chae, U., \& Park, Y. (2018). Asian Nursing Research Development and Cross Validation of the Short Version of the Cultural Competence Scale for Nurses. Asian Nursing Research, (March), 1-8. https://doi.org/10.1016/j.anr.2018.02.004

Chae, D., \& Park, Y. (2018). Organisational cultural competence needed to care for foreign patients: A focus on nursing management, (June 2017), 1-10. https://doi.org/10.1111/jonm.12665

Curwick K, Dutt T.(2015). Cultural competence in acute and critical care medicine literature review and recommendations. Critical Care Medicine 2015;43(12): 142.

Cross, T., Bazron, B., Denis,K. And Issacs, M., 
Faletehan Health Journal, 7 (1) (2020) 52-61 www. journal.Ippm-stikesfa.ac.id/ojs/index.php/FHJ ISSN 2088-673X | 2597-8667

(1989). Toward a culturrally compe- tent system of Care . Volume 1. Washing- ton DC: Georgetown Universty.

El-amouri, S., \& Neill, S. O. (2016). Supporting cross-cultural communication and culturally and culturally diverse hospital, 6178(March). https://doi.org/10.5172/conu.2011.39.2.240

Flowers, D. (2004). Culturally Competent Nursing Care, 24(4), 48-53.

Guru. Y, Suryani \& Nursiswati, (n.d.). Analisa Kebutuhan Komunikasi pada Pasien dengan Ventilator makanik Selama di Ruang General Intasive Care Unit (GICU) RSUP Dr. Hasan Sadikin Bandung, 1-14.

Grossbach I., Stranberg S., Chlan L.,(2011), Promoting Effective Communication for Patients Receiving Mechanical Ventilation. American Association of Critical Care Nurses, 31:46-60.

Hart, P. L., \& Mareno, N. (2013). Cultural challenges and barriers through the voices of nurses, https://doi.org/10.1111/jocn.12500

Holloway, I. \& Wheeler, S. (2010). Qualitative Research in Nursing, Blackwell Publishing, United Kingdom.

Hendson, L., Reis, M. D., Nicholas, D. B., \& Hendson, L. (2015). Health Care Providers ' Perspectives of Providing Culturally Competent Care in the NICU, 17-27. https://doi.org/10.1111/1552-6909.12524

Høye, S., \& Severinsson, E. (2010). Professional and cultural conflicts for intensive care nurses. $\quad$ https://doi.org/10.1111/j.13652648.2009.05247.x

Hudak \& Gallo (2010). Keperawatan Kritis Edisi 6. Jakarta; EGC

Im, E., \& Lee, Y. (2018). Transcultural Nursing: Current Trends in Theoretical Works. Asian Nursing Research, (September). https://doi.org/10.1016/j.anr.2018.08.006

Karabudak. S. S, Tas. F, \& Basbakkal, Z (2013). Giger and Davidhizar's Transcultural Assessment Model: A Case Study in Turkey, 7, 342-345.
Leininger, M. M., \& McFarland, M. R. (2002). Culture care diversity and universality: A worldwide nursing theory. Sudbury, MA: Jones and Bartlett.

Mcfarland, M. R., Learning, B., \& Wehbealamah, H. B. (n.d.). The Theory of Culture Diversity and Universality.

Nuraeni, A., Ibrahim, K., \& Agustina, H. R. (2013). Makna Spiritualitas pada Klien dengan Sindrom Koroner Akut Meaning of Spirituality among Clients with acute corronary syndrome, 1, 79-87.

Ozga, D., Dobrowolska, B., Gutysz-wojnicka, A., \& Zdun, A. (2018). Multicultural Care in European Intensive Care Units ( MICE-ICU ) - international project for ICU nurses, 5051. https://doi.org/10.2478/pielxxiw-20180008

Purnell, L. (2002). The Purnell Model for Cultural Competence. Journal of Transcultural Nursing, 13 (3), 193 - 196. https : // doi. org / 10. 1177 / 10459602013003006

Schim, S. M., \& Miller, J. (2007). Culturally Congruent Care: Putting the Puzzle Together, 18(2), 103-110. https://doi.org/10.1177/1043659606298613

Schim, S. M., Doorenbos, A. Z., \& Borse, N. N. (2006). Cultural Competence Among Hospice Nurses, 8(5).

Unger J. B. \& Schwartz S. J. (2012). Conceptual considerations in studies of cultural influences on health behaviors. Preventive Medicine, 55(5): 353-355

Vu, T., Agarwal, P., Mccullough, J., Lipshutz, A., Turner, K., Anderson, W., In-, U. C. C. (2015). Engaging an ICU patient and family advisory council to redeign a patient oriented website care medicine : literature review and recomendation, 43(12), 2015.

WFCCN. Brisbane declaration: Culturally sensitive critical care nursing. http://www. hdmsarist.hr/wpcontent/uploads/2016/10/WFCCN-BrisbaneDeclaration.pdf. 2016 